\title{
PENGGUNAAN BUTOH-FU (NOTASI BUTOH) DALAM PENGKARYAAN \\ KOREOGRAFI: KAJIAN KES PRODUKSI REMINISCENCE, THE WORLD OF THE STRANGE TALES (2013) \\ THE USE OF BUTOH-FU (BUTOH NOTATION) IN CHOREOGRAPHY: \\ A CASE STUDY OF REMINISCENCE, THE WORLD \\ OF THE STRANGE TALES (2013)
}

\author{
${ }^{1}$ Leng Poh Gee \\ ${ }^{2}$ Mumtaz Begum Aboo Backer \\ Universiti Pendidikan Sultan Idris \\ Universiti Sains Malaysia \\ lengpg@yahoo.com; mumzie@usm.my \\ Tarikh dihantar: 20 Januari 2021 Tarikh diterima: 30 Mac 2021
}

\begin{abstract}
ABSTRAK
Butoh-Fu (Notasi Butoh) telah diciptakan oleh pengasas butoh, Hijikata Tatsumi (1928-1986) dan disusun oleh pelajarnya, Yukio Waguri (19522017) secara retrospektif. Butoh-Fu digunakan sebagai satu kaedah koreografi. Kaedah tersebut telah diperkenalkan kepada penari tempatan oleh Yukio Waguri sejak akhir tahun 2000-an. Artikel ini menerangkan perkembangan seni butoh khususnya di Semenanjung Malaysia dan menjelaskan peranan Butoh-Fu dalam pengkaryaan, melalui kajian kes produksi Reminiscence, The World of the Strange Tales (2013), di mana penulis terlibat sebagai penari. Data yang diperolehi melalui kaedah pemerhatian ikut serta, temu bual kumpulan dan refleksi kendiri telah diwacanakan untuk mengisi kekosongan mengenai perkembangan butoh dalam penyelidikan seni tari tempatan. Artikel ini turut mencadangkan bahawa memiliki satu sistem notasi yang dicipta dan diguna khas oleh komuniti pengamalan sendiri adalah berkesan dalam mempercepatkan pengenalan sesuatu genre tari, serta relevan dalam perakuan autoriti professionalisme.
\end{abstract}

Kata kunci: Notasi tari, koreografi, butoh, Butoh-Fu.

\section{ABSTRACT}

Butoh-Fu (Butoh Notation) was created by the founder of butoh, Hijikata Tatsumi (1928-1986) and compiled by his student, Yukio Waguri (19522017) retrospectively. Butoh-Fu is used as a choreographic method. The method has been introduced to the local dancers by guru Yukio Waguri (1952-2017) since the late 2000's. This article describes the development of butoh especially in peninsular Malaysia, and explains the role of Butoh-Fu in dance creation and performance, through stage production Reminiscence, The World of the Strange Tales (2013) as 
a case study, which I was involved as a dancer. Data obtained through the methods of participant observation, group interviews and self-reflection were made as a discourse to fill in the absence of butoh's development in local dance research. This article also suggests that a notation system that was created and used by its community of practitioners, is indeed effectively speed up the circulation of the dance genre and relevant to enhance its authority of professionalism.

Keywords: Dance notation, choreography, butoh, Butoh-Fu.

\section{PENGENALAN}

\section{Latar Belakang Butoh}

Jepun menyerah kalah dalam Perang Dunia Kedua pada tahun 1945 dan kemudian mengalami proses pemulihan di bawah pengaruh Amerika Syarikat melalui perjanjian Treaty of Mutual Coorperation and Secirity Between the United States and Jepun (Karaoğlu, 2020). Oleh hal yang demikian, masyarakat Jepun bukan sahaja mengalami proses modenisasi, tetapi juga menghadapi proses 'Amerikanisasi' dari segi ekonomi, politik dan budaya. Dalam transisi daripada nilai tradisi Jepun ke nilai demokrasi yang dipengaruhi oleh budaya Amerika, pelbagai isu seperti kebangkitan nasionalisme, persoalan kepada makna pemodenan dan keinginan untuk mempertahankan budaya tempatan telah dibangkitkan di kalangan ahli intelektual, termasuk seniman yang berusaha mencari ekspresi baharu yang dapat memaparkan identiti Jepun (Ling, 1998). Dalam seni tari, Hijikata Tatsumi (1928-1986) dan Kazuo Ohno (1906-2010) mengasaskan genre tari butoh yang bukan sahaja ingin menentang kongkongan estetik seni tari Barat (tari balet dan moden), tetapi juga mencabar seni persembahan tradisi Jepun yang amat berpengaruh seperti teater Kabuki dan Noh (Klein, 2007; Fraleigh, 2010).

Butoh mempunyai imej penampilan dan cara persembahan yang amat unik dan mudah dikenal pasti seperti berkepala botak, bertelanjang, badan diselaputi dengan solekan putih, berpenampilan transvestisme, mengamalkan fahaman minimalisme, bersifat spiritual, melibatkan perihal seksual, keganasan dan kekacauan. Perbendaharaan gerak tari butoh biasanya melanggar prinsip pergerakan semula jadi manusia dan banyak berasaskan kualiti gerak geri binatang liar, serangga, hantu (secara imaginasi). Imej sebegini dianggap mampu memaparkan konflik, kehodohan, nafsu, sifat mementingkan diri dan kemudahrapuhan yang sememangnya wujud dalam manusia yang bertamadun (Klein, 2007; Fraleigh, 2010). 
Hijikata Tatsumi telah melatih ramai koreografer butoh yang terkenal dan berpengaruh di peringat antarabangsa. Mereka melakukan pelbagai pengubahsuaian dan adapatsi ke atas butoh dari semasa ke semasa mengikut arus perkembangan konsep estetik kegemaran dan tuntutan sosial masing-masing seperti Akaji Maro yang masih mengekalkan identiti butoh aliran asal pengasas Hijikata; Ushio Amagatsu yang mementingkan imej 'zen, cerah, bersih, dan tidak berbahaya'; Eiko dan Koma yang memaparkan keindahan kebogelan; mendiang Yukio Waguri, yang berminat dalam pengkaryaan persilangan budaya melalui interpretasi Butoh-Fu (Notasi Butoh) dan lain-lain lagi. Daripada pencarian dan pengukuhan identiti budaya Jepun yang menentang pengaruh Barat mahupun seni tradisional Jepun, butoh kini berkembang bukan sahaja menjadi satu metod latihan fizikal persembahan, tetapi juga sebagai satu amalan falsafah yang boleh meluahkan ekspresi antara duniawi dengan spiritual dan menghujahkan manifestasi pascakolonial antara golongan pinggiran dengan kuasa hegemoni seperti yang dicadangkan oleh Fraleigh (2010):

Is butoh a philosophy? Yes, it is unfinished metaphysical philosophy of the dancing body that accounts for weakness and death, identifying with nature, decay, regeneration, and transformation. Its context is metamorphic and its politics anti-utopian. Its darkness is spiritual and beyond material. Born of mud and morphing to silk, its aesthetic is both beautiful and ugly, and its spiral emotion into metaphysics. Its elchemy moves through the in ineffable spaces "in between" (ma, in Japanese). Its awkward "going under", or "frog 's-eye view", seeks an end to heroic ascalating power struggles and war. Its direction is descent, and its material tendency is toward dissolution. The cultivation of creative interspaces in butoh has promoted a global morphology that continues to evolve. (p.76)

\section{Butoh-Fu (Notasi Butoh) dan Yukio Waguri}

Pengasas butoh, Hijikata Tatsumi menggunakan banyak istilah atau ungkapan sebagai rujukan semasa menghasilkan koreografi. Setiap istilah atau ungkapan itu mewakili satu ragam gerak yang khusus. Namun, interpretasi gerak bagi setiap istilah atau ungkapan itu adalah berbeza mengikut tempoh penghasilan, penari dan persembahan (Waguri, 2004; Hensbergen, 2019). Istilah atau ungkapan itu dikenali sebagai $f u$. $F u$ diterjemahkan sebagai skor atau notasi yang harus dibentangkan dalam bentuk dokumentasi tulisan. Para penari Hijikata lazimnya mempunyai koleksi fu masing-masing yang tersendiri untuk mengingatkan pelaksanaan koreografi butoh Hijikata (Hensbergen, 2019). 
Pada tahun 2004, Yukio Waguri telah menerbitkan Butoh Kaden dalam bentuk DVD, yang mengumpulkan 88 jenis $f u$. Waguri mengenali koleksi $f u$ ini sebagai Butoh-Fu. Inventori Butoh-Fu yang dikumpul dan disusun semula ini merupakan hasil ingatan daripada nota pembelajaran Yukio Waguri dalam proses pengkaryaan koreografi Hijikata sejak tahun 1970-an. Penari atau pembaca boleh mempersembahkan semula sesuatu repertoir dengan merealisasikan imej-imej yang diungkapkan oleh urutan Butoh-Fu. Yukio Waguri menerbitkan Butoh Kaden atas niat ingin memperkembangkan kaedah koreografi Hijikata sebagai satu kaedah penerokaan pergerakan dan satu kaedah permulaan koreografi butoh, di samping mengurangkan stereotaip umum yang menganggap bahawa persembahan butoh adalah semata-mata bergantung kepada improvisasi sepenuhnya (Waguri, komunikasi peribadi, 30 Ogos 2013).

BUTOH-FU is a word-based notation and it was initially created by Hijikata in order to choreograph butoh performance. BUTOH-FU embraces our bodies and the process of transformation through associations triggered by words. The rich and diverse world that BUTOH-FU offers has become a standard not only for butoh students but also for many people seeking new inspiration. Welcome to a world of imagination spurred by words, and the rich expression that our bodies can achieve! (Waguri, 2004).

Butoh-Fu yang lazimnya bersifat puitis dan abstrak telah dikodifikasikan oleh Yukio Waguri. Berdasarkan kualiti analisis pergerakan, beliau telah mengkategorikan Fu kepada Tujuh Dunia (Seven Worlds of Butoh-Fu), iaitu (1) World of Anatomy, (2) World of Burnt Bridges, (3) the World of Walls, (4) the World of Birds and Beasts, (5) the World of Flowers, (6) the World of the Neurology Ward, serta (7) the World of Abyss (Waguri, 2004). Penjelasan kualiti gerak dan contoh-contoh Butoh-Fu dalam Dunia yang berbeza dipaparkan dalam Jadual 1.

Jadual 1 Penerangan Tujuh Dunia Butoh-Fu

\begin{tabular}{|c|c|c|c|}
\hline Bil. & Tujuh Dunia & Penerangan Kualiti Gerak & Contoh-contoh Butoh-Fu \\
\hline 1. & $\begin{array}{l}\text { Dunia Anatomi } \\
\text { (World of Anatomy) }\end{array}$ & $\begin{array}{l}\text { Tubuh manusia telah } \\
\text { dicairkan seperti pengaliran } \\
\text { lava dan tiada bentuk yang } \\
\text { tetap. }\end{array}$ & $\begin{array}{l}\text { Hidung disempit secara } \\
\text { melampau. Hidung } \\
\text { menjangkau ke bawah pipi } \\
\text { kiri. } \\
\text { Jari telunjuk memanjangkan } \\
\text { diri tanpa berhenti. Apabila } \\
\text { ia mencapai ke titik akhir, } \\
\text { dandelion mekar di telinga } \\
\text { dan lebih banyak dandelion } \\
\text { mekar di mulut. }\end{array}$ \\
\hline
\end{tabular}




\begin{tabular}{|c|c|c|c|}
\hline 2. & $\begin{array}{l}\text { Dunia Jambatan } \\
\text { Terbakar } \\
\text { (World of Burnt } \\
\text { Bridges) }\end{array}$ & $\begin{array}{l}\text { Tubuh manusia yang kasar } \\
\text { dibentuk daripada keadaan } \\
\text { kekacauan. }\end{array}$ & $\begin{array}{l}\text { - Tiang antara langit dan bum } \\
\text { dibakar oleh api neraka dan } \\
\text { sedang berasap. } \\
\text { - Orang itu menderita } \\
\text { kerana cirit-birit, dan hujan } \\
\text { turun tanpa belas kasihan } \\
\text { kepadanya. }\end{array}$ \\
\hline 3. & $\begin{array}{l}\text { Dunia Dinding } \\
\text { (World of Walls) }\end{array}$ & $\begin{array}{l}\text { Manusia kini mengenal } \\
\text { pasti bahan pembinaan yang } \\
\text { berbeza seperti tanah, batu } \\
\text { dan pasir. }\end{array}$ & $\begin{array}{l}\text { - Seseorang menjadi seperti } \\
\text { kulit kayu. Belakangnya } \\
\text { adalah penuh dengan } \\
\text { serangga. }\end{array}$ \\
\hline 4. & $\begin{array}{l}\text { Dunia Burung dan } \\
\text { Haiwan } \\
\text { (World of Birds and } \\
\text { Beasts) }\end{array}$ & $\begin{array}{l}\text { Kewujudan pelbagai bentuk } \\
\text { yang kompleks. }\end{array}$ & 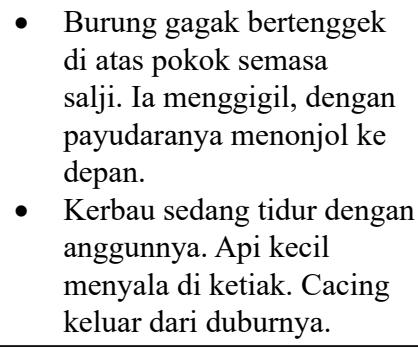 \\
\hline 5. & $\begin{array}{l}\text { Dunia Bunga } \\
\text { (World of Flowers) }\end{array}$ & $\begin{array}{l}\text { Menggariskan tema } \\
\text { pertumbuhan, kemalapan, } \\
\text { penyebaran, dan menjadikan } \\
\text { benih bijirin atau bunga } \\
\text { yang memenuhi ruang. }\end{array}$ & $\begin{array}{l}\text { Badan anda diperbuat } \\
\text { daripada debunga bunga. } \\
\text { Hujung jari anda mencubit } \\
\text { benang seolah-olah anda } \\
\text { sedang menganyam. }\end{array}$ \\
\hline 6. & $\begin{array}{l}\text { Dunia Neurologi } \\
\text { (World of Neurology) }\end{array}$ & $\begin{array}{l}\text { Imej pertumbuhan saraf yang } \\
\text { halus yang membahagikan } \\
\text { diri, menggandakan diri, } \\
\text { dan memanjangkan diri ke } \\
\text { ruang. }\end{array}$ & $\begin{array}{l}\text { Kuda itu kemudian menjadi } \\
\text { siput besar. Siput kemudian } \\
\text { menjadi hantu yang sedang } \\
\text { membawa bayi di mulutnya. } \\
\text { - } \quad \text { Dia merenung dua titik di } \\
\text { udara. Rumput tumbuh } \\
\text { dari bahagian perutnya } \\
\text { membahagikan dadanya } \\
\text { kepada dua bahagian. }\end{array}$ \\
\hline 7. & $\begin{array}{l}\text { Dunia Jurang } \\
\text { (World of Abysses) }\end{array}$ & $\begin{array}{l}\text { Benih atau saraf yang } \\
\text { semakin memenuhi ruang } \\
\text { mengalami penguraian dan } \\
\text { menjadi ruang atau cahaya. }\end{array}$ & $\begin{array}{l}\text { - Terdapat strawberi di mata } \\
\text { anda. Mawar mekar di } \\
\text { mulut anda. Dandelion } \\
\text { tumbuh dari telinga anda. }\end{array}$ \\
\hline
\end{tabular}

Sumber: Susun semula berdasarkan Butoh Kaden (Waguri, 2004).

Setiap unit Butoh-Fu yang dipaparkan di Jadual 1 boleh digunakan secara berasingan atau tunggal, atau digabungkan dengan Butoh-Fu yang lain. Butoh-Fu ini bukan sahaja menyampaikan cara melaksanakan gerak, tetapi juga menerangkan sikap tubuh dan ekspresi muka yang dijangkakan dalam Dunia yang berbeza. 
Waguri's exposition is the first and, to date, only published source through which the public can access the alchemical process of Hijikata's ButohFu. While Hijikata's Butoh-Fu are poetic, they nevertheless show clear notation for performance, not in the style of Western notation like the Laban system, but pictorially and imagistically and within a cosmological outline, moving through seven worlds from wet and heavy to light and airy. (Fraleigh, 2010, hlm. 43)

\section{Perkembangan Butoh di Semenanjung Malaysia}

Permulaan perkembangan tari butoh di Semenanjung Malaysia bermula seawal tahun 1990an dan diperkenalkan oleh Lena Ang Swee Lin (1964) (Gonzales, 2019; Lim, 2014; Leng, 2011, 2009). Lena yang berasal dari Pulau Pinang merupakan salah seorang tenaga pengajar perintis di Akademi Seni Kebangsaan, yang kini dikenali sebagai Akademi Seni Budaya dan Warisan Kebangsaan (ASWARA). Beliau kagum dengan persembahan Eiko \& Koma, yang menekankan keindahan seni bogel melalui butoh, dan terus melibatkan diri dalam genre tarian tersebut. Lee Swee Keong merupakan salah seorang anak muridnya yang kemudiannya memainkan peranan yang amat penting dalam mempromosikan persembahan butoh di Semenanjung Malaysia.

Pada tahun 1995, Lee menubuhkan Nyo-ba \& Dancers, yang kemudian ditukar nama kepada Nyoba Kan pada tahun 2006. Beliau merupakan pengarah artistik sejak awal tahun 1995 sehingga kini. Kumpulan tersebut mengutamakan persembahan dan pengkaryaan yang bersifat eksperimental yang mengamalkan minimalisme, transvestisme, mementingkan kolaborasi dengan artis-artis daripada bidang lain, serta memanipulasi tema-tema yang berkaitan dengan seksual dan keganasan. Kumpulan ini masih mengekalkan beberapa keunikan penampilan imej butoh seperti transvestisme, separuh bogel (hanya pemakaian cawat lelaki), dan solekan putih pada badan. Demi mempromosikan butoh dalam kalangan umum, festival butoh di peringkat antarabangsa telah dianjurkan sejak 2010 sehingga kini. Beliau kini merupakan pengajar yoga sepenuh masa dan cuba menghasilkan persembahan tari yang menggabungkan falsafah Buddhisme, zen, qigong dan taici (Leng, 2011, 2009).

Yeow Lai Chee, salah seorang bekas penari Nyoba Kan, menubuhkan kumpulan butoh Soubi Sha pada tahun 2012, setelah mendapat inspirasi dan galakan daripada mentor-gurunya, mendiang Yukio Waguri (Yeow, L.C., komunikasi peribadi, 17 Julai 2019). Oleh itu, Yeow giat menjemput Yukio Waguri untuk mengarahkan pelbagai persembahan, bengkel dan seminar. Pada tahun 2013, Yukio Waguri telah menghasilkan Reminiscene, The World of The Strange Tales (Reminiscene), sebagai produksi pembukaan bagi kumpulan butoh Soubi Sha. 
Penulis berpeluang menyertai produksi Reminiscene sebagai penari, sekali gus membolehkannya mengenali Butoh-Fu yang dijadikan titik permulaan dan rujukan peringatan bagi kaedah koreografi amalan Hijikata Tatsumi. Metodologi pemerhatian ikut serta dan temu bual, sama ada secara individu atau berkumpulan telah dijalankan sepanjang tempoh penghasilan karya untuk memperoleh data yang menyumbangkan kepada pemahaman, penggunaan dan peranan sistem notasi tari dalam aspek perkembangan seni tari butoh. Penggunaan notasi tari lazimnya dijadikan sebagai salah satu cara untuk memelihara, melestari dan menganalisis gerak tari dalam konteks penyelidikan tari tempatan (Nor, 2014, 2008, 1998, 1993, 1986) dalam domain akademik. Walau bagaimanapun, fenomena penggunaan notasi tari sebagai satu kaedah untuk menjana pergerakan untuk penghasilan koreografi adalah kurang diwacanakan.
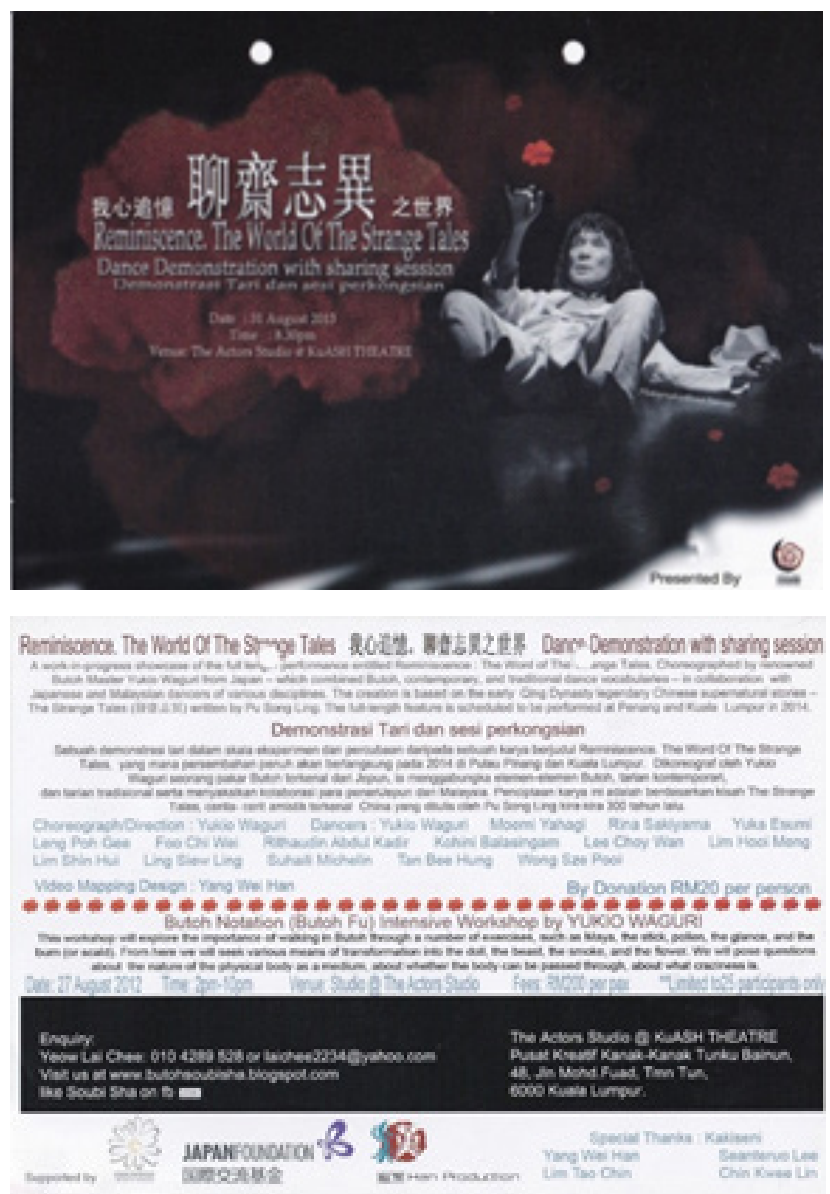

Rajah 1 Brosur persembahan Reminiscence

Sumber: Agihan pementasan Reminiscene arahan Yukio Waguri, yang dilangsungkan pada 31 Ogos 2013 di The Actors Studio@ KuASH Theatre 


\section{Pengkaryaan berdasarkan Butoh-Fu dalam Reminiscence (2013)}

Pementasan Reminiscene merupakan sebuah hasil karya arahan dan koreograf Yukio Waguri, yang dilangsungkan pada 31 Ogos 2013 di The Actors Studio @ KuASH Theatre, Kuala Lumpur (Rajah 1). Barisan penari terdiri daripada tiga penari Jepun serta 11 orang penari tempatan daripada berbilang kaum dan latar belakang latihan tari. Penari-penari menjalani latihan raptai dengan berdasarkan Butoh-Fu, atau kaedah Hijikata secara sangat intensif selama tiga hari. Dengan kata lain, Reminiscence merupakan satu pembentangan hasil bagi usaha selama tiga hari. Reminiscence dipentaskan sebagai satu sesi pertunjukan demonstrasi seni tari butoh yang bersifat eksperimental dan diakhiri dengan sesi perbincangan. Sifat eksperimental di sini merujuk kepada pencarian pelbagai kemungkinan dalam konteks persembahan budaya silang, termasuk mengenal pasti watakwatak berdasarkan kekuatan para penari tempatan, mengintegrasikan unsur-unsur seni lokal seiring dengan struktur naratif dan pengarahan artistik persembahan butoh. Dalam pada itu, menjalinkan hubungan yang saling mempercayai dan membina keyakinan di kalangan penari adalah sangat mencabar dalam tempoh tiga hari raptai.

Yukio Waguri telah menetapkan struktur persembahan yang terdiri daripada pelbagai segmen, dan setiap segmen itu boleh terdiri daripada solo, duet, trio atau ensemble (Jadual 2). Walau bagaimanapun, niat dan pengarahan artistik koreografi Yukio Waguri bukanlah topik yang ingin diketengahkan dalam artikel ini, malah penggunaan Butoh-Fu dalam sesi komposisi dan improvisasi untuk pengkaryaan adalah tunjang perbincangan. Untuk membahaskan aplikasi tersebut, satu persembahan solo dan satu ensembel dipilih sebagai analisis.

Jadual 2 Struktur persembahan Reminiscene

\begin{tabular}{|c|l|c|}
\hline \multicolumn{1}{|c|}{ Susunan Segmen } & Bilangan Penari \\
\hline 1. & Shaman & 1 \\
\hline 2. & White Ghost & 6 \\
& (1) Kumpulan & 1 \\
\hline 3. & Fox Solo & 5 \\
\hline 4. & Hell & 7 \\
\hline 5. & Flowers & 1 \\
& (1) Tarian klasik India (Bharata Natyam) & 2 \\
& (2) Tarian Cina (payung sebagai peralatan) & 2 \\
& (3) Tarian klasik Jepun (kipas lipat sebagai peralatan) & 1 \\
& (4) Tarian klasik India (Odisi) & \\
\hline
\end{tabular}




\begin{tabular}{|c|l|c|}
\hline 6. & Dead Beauty & 5 \\
& $(1)$ Kumpulan & 2 \\
& $(2)$ Tarian Igal & \\
\hline 7. & Water & 9 \\
& $(1)$ Kumpulan & 1 \\
& $(2)$ Solo & \\
\hline
\end{tabular}

\section{Analisis 1: Persembahan Solo dalam Segmen The White Ghost}

Dalam persembahan solo ini, penulis dipilih sebagai pemain solonya. Dalam proses koreografi, tiada demostrasi pergerakan ditunjukkan yang membolehkan penulis melakukan imitasi, dan satu senarai $F u$ telah diagihkan oleh Yukio Waguri kepada penulis. Senarai $F u$ yang dijadikan panduan improvisasi dan komposisi mengikut urutan adalah seperti berikut:

- $\quad$ Anda terdengar loceng berbunyi dan menuju ke arah itu.

- Anda terjumpa sekuntum bunga yang sebenarnya berada di dalam tangan sendiri.

- $\quad$ Anda memetik kelopak bunga dengan menggunakan saluran saraf anda yang sangat halus seperti jarum.

- $\quad$ Anda kekejangan, lantas teringat bahawa anda mempunyai jari.

- Anda teruskan memetik kelopak bunga dengan menggunakan jari dan kemudian melibatkan keseluruhan tangan secara aktif.

- $\quad$ Anda terjumpa sebatang kayu yang menegak dan sedang berputar, sehingga berubah menjadi seekor ular.

- Ular itu bergerak menuju anda dan melompat masuk ke dalam mulut anda.

- Ular itu menjadi batang kayu semula dalam perut anda.

- $\quad$ Anda memasang satu topeng yang tiada gigi.

- $\quad$ Muka anda menjadi bengkak dan cahaya bulan menyirami muka anda.

- $\quad$ Anda berjalan dengan sebelah kaki yang bercahaya dan sebelah kaki lagi adalah bebayang.

- $\quad$ Anda adalah seekor lembu yang semakin reput.

- Terdapat dakwat ditaburkan ke muka anda yang menyebabkan bentuk muka anda diherot-herotkan.

- Anda marah, dan melangkah ke hadapan.

- Anda terhidu sesuatu daripada badan anda.

- Anda adalah air terjun. 
Dengan memiliki Butoh-Fu tersebut, penulis diberikan masa untuk berlatih sendiri dan ia merupakan satu pengalaman yang sangat seksa di samping melucukan. Biarpun Butoh-Fu yang diagihkan adalah mengarut kedengarannya, tetapi imej-imej imaginasi yang tergambar dalam minda tetap perlu direalisasikan melalui pergerakan. Hasil percubaan penulis dibentang kepada beliau dari semasa ke semasa untuk mendapatkan maklum balas. Beliau tetap jarang mendemonstrasi pergerakan, tetapi amat menegaskan kepada reaksi yang setia terhadap permintaan setiap Fu sama ada dalaman (emosi) atau luaran (fizikal). Sebagai contoh, salah satu Fu yang berbunyi: "Anda memasang satu topeng yang tiada gigi." Secara konvensinya, penulis melakonkan ekspresi muka yang tenang, kaku dan mulut ditutup secara relaks dengan mengandaikan muka dilindung di bawah topeng. Namun, penulis diminta supaya tiada sebarang pergerakan pada muka termasuk mata terpejam, dan bukan sahaja tidak boleh menampakkan gigi, tetapi seluruh mulut 'dibuangkan'. "Pernahkah anda melihat nenek tua yang sangat uzur, tiada gigi dan tidak bermaya untuk membuka mulut lagi? Pernahkah anda merasai bagaimana mulut banduan atau mangsa seksaan dijahit?" beliau bertanya. Beliau 'memaksa' penulis mengingati dan meluahkan pengalaman yang berkaitan dengan pengalaman 'suara dilenyapkan' atau dianiaya - merenung kembali pengalaman peribadi tersebut boleh menjadi sesuatu yang menyesakkan. Penulis mula menyedari bahawa Yukio Waguri mewajarkan hubungan antara $F u$, gerak dan emosinya.

Komen beliau tidak bersifat langsung dari segi pelaksanaan gerak, malah lebih memimpin untuk melakukan metamorfosis (metamorphosis) ke atas diri sendiri, dan seterusnya membentukan imej yang aneh (grotesque imagery). Kedua-dua pendekatan metamorfosis dan grotesque imagery digunakan untuk menghilangkan individualisme diri melalui pengakuran diri ke kuasa alam. Pemain butoh wajib mengalami proses metamorfosis dan 'menjelmakan' diri kepada flora, fauna, objek-objek atau peristiwa yang dinyatakan dalam Tujuh Dunia Butoh-Fu, untuk membolehkan pemain berkomunikasi dengan perasaan diri secara dalam dan jujur. Pemutarbelitan yang terlampau pada otot muka dan bahagian-bahagian badan sehingga grotesque berlaku adalah satu perakuan yang tidak menafikan kewujudan nilai-nilai negatif diri kita seperti nafsu, kejahatan, kesedihan dan kehodohan yang terpendam. Imej grotesque adalah satu manifestasi antiutopia (Klein, 2007).

Berdasarkan pembentangan-pembentangan penulis, beliau memilih, mengubah suai dan menetapkan pergerakan tersebut secara teliti dari segi masa, arah, aras dan bahagian-bahagian badan yang melaksanakan gerak. Beliau boleh mengesan nuasa-nuansa gerak yang tercicir, atau tidak menepati urutan - tiada 
improvisasi yang di luar susunan dibenarkan, dan hal ini telah mengubah salah anggap saya terhadap persembahan butoh yang hanya berlandaskan improvisasi semata-mata. Dalam melaksanakan $F u$, penulis telah merasai kualiti gerak yang berbeza dalam Tujuh Dunia Butoh-Fu seperti "Anda memasang satu topeng yang tiada gigi" dari Dunia Anatomi; "Anda adalah seekor lembu yang semakin reput" dari Dunia Burung dan Haiwan; "Anda terjumpa dengan sebatang kayu yang menegak, dan kayu itu sedang berputar, sehingga menjadi seekor ular” dari Dunia Dinding, dan lain-lain lagi. Dari aspek latihan teknik, penulis semakin mendalami pelbagai kualiti gerak seperti ketumpatan, kecairan, keringanan dan pemeluwapan tubuh sendiri - latihan tersebut adalah sinonim dengan pengalaman pembelajaran Analisis Gerak Laban (Laban Movement Analysis) yang menekankan pelbagai kualiti gerak yang kontras di dalam elemen berat (weight), pengaliran (flow), masa (time) dan ruang (space).

Dalam analisis pengkaryaan koreografi ini, keberkesanan Butoh-Fu telah melangkaui fungsinya sebagai hanya notasi tari, tetapi membantu penari mengkaji semula makna gerak dari pelbagai perspektif. Butoh-Fu tidak berniat untuk melatih pemain butoh sepenuhnya, tetapi membangkitkan emosi dan pengalaman silam individu, dan seterusnya meningkatkan penghargaan kendiri melalui ekspresi gerak.

\section{Analisis 2: Persembahan Ensembel dalam Segmen Dead Beauty}

Karya seni lukis memainkan peranan yang penting dalam pengkaryaan koreografi kaedah Hijikata kerana sesetengah pengungkapan $F u$ adalah imaginasi lanjutan atau imitasi ke atas karya lukisan seni yang agung seperti karya seni daripada Hans Bellmer (1902-1975) dan Jean Delville (1867-1953) dari Barat; serta Ito Jakuchu (1716-1800) dan Soga Shohaku (1730-1781) dari Jepun.

Dalam persembahan kumpulan Dead Beauty, hasil karya seni surealisme Paul Delvaux (1897-1994) seperti The Road to Rome (1979), The Tunnel (1978) dan The Night Garden (1942) telah dipilih untuk penjanaan komposisi. Ciri-ciri karya seni Paul Delvaux dinyatakan seperti berikut:

Most of his paintings show nude or semi-nude women in incongruous settings. The women are always of the same type - beautiful, statuesque, unattainable dream figures, lost in thought or reverie or even in a state of suspended animation. These dream beauties are often placed in elaborate architectural settings, reflecting both de Chirico's strange perspectives and Delvaux's interest in the buildings of ancient Rome. Sometimes he included skeletons in his pictures and trains were another recurrent motif (Chilvers, 2003). 
Berdasarkan karya-karya lukisan ini, Yukio Waguri mengarahkan para penari melakukan imitasi ke atas posisi-posisi wanita sebagaimana yang dilukiskan. Para penari bukan sahaja meniru posisi gerak dari segi bentuk badan, bentuk bahagian-bahagian badan, arah dan aras, tetapi turut meniru kualiti ekspresi muka seperti patung, peralihan berat tubuh badan yang perlahan dan bertahan seperti dalam alam pengaliran masa yang telah diperlahankan. Hubungan antara penari dengan penari yang lain, mahupun penari dengan objek yang lain turut dikekalkan sebagaimana karya seni lukis. Beberapa karya seni telah diagihkan kepada barisan penari yang berkaitan dan diberikan masa untuk berlatih secara berkumpulan. Para penari perlu menghafal posisi dan gerak mereka yang berbeza mengikut susunan beberapa lukisan. Pembentangan diadakan dari semasa ke semasa, penghalusan komposisi dilakukan dan permintaan pelaksanaan $\mathrm{Fu}$ terhadap penari ditambahkan. Dalam hal ini, karya lukisan seni yang bersiri telah dijadikan notasi tari.

Yukio Waguri sangat tegas dalam memastikan barisan penarinya mengikut notasi karya lukisan dengan teliti dan ketat. Sebagai contoh, penari di Rajah 2 melakukan imitasi aksi gerak yang sama sepenuhnya seperti dua watak wanita yang dilukiskan di sebelah kanan dalam hasil karya seni The Night Garden $(1942)^{1}$. Yukio Waguri menegaskan bahawa kemasyhuran dan signfikan sesuatu hasil seni lukis yang klasik terletak pada peletakan posisi objek/hidupan, ketepatan nisbah, susunan struktur gambar dan prospektif imej yang mampu berdepan dengan ujian masa - dan para penari tidak harus mengingkarinya.

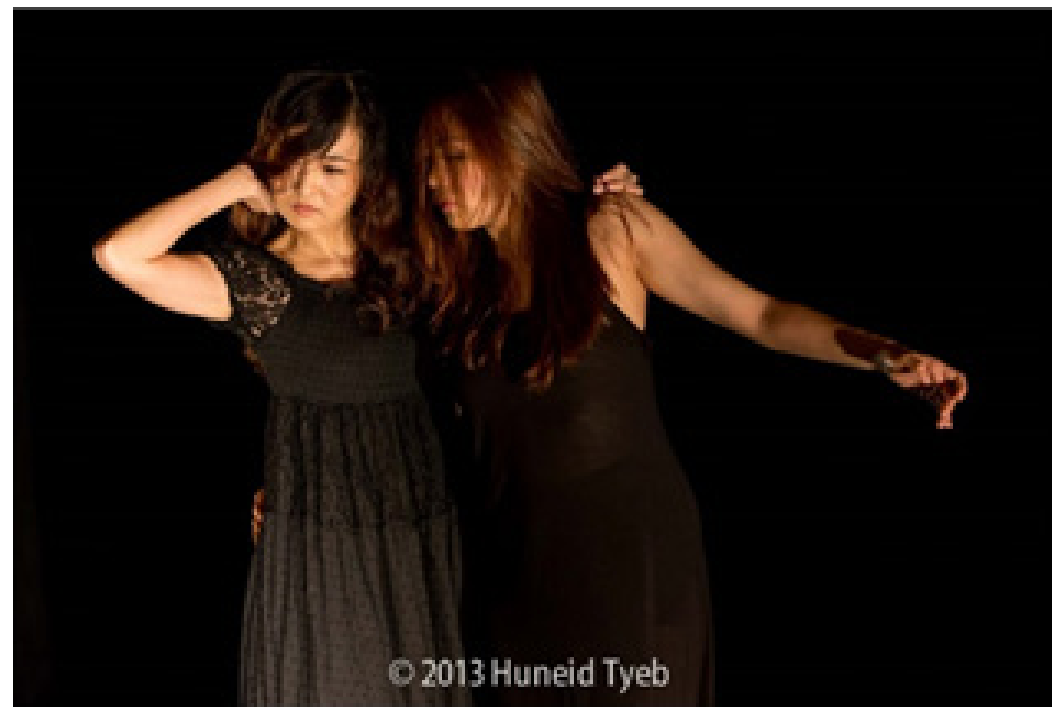

Rajah 2 Posisi penari yang mengikuti lukisan seni The Night Garden (1942) Sumber: Huneid Tyeb (2013). 


\section{KESIMPULAN}

Bertitik tolak dari kemunculan seni butoh di Jepun sebagai satu reaksi terhadap pasca Perang Dunia Kedua, butoh kini telah berkembang menjadi satu bentuk seni yang berkaitan dengan latihan teknik semata-mata untuk fizikal (pure physical technique training), dan juga berkaitan dengan paparan ketegangan di antara kuasa hegemoni dengan budaya pinggiran di peringkat antarabangsa (Baird \& Candelario, 2019). Perkembangan seni butoh di Malaysia adalah dimulakan daripada Lena Ang Swee Lin, diikuti dengan Lee Swee Keong, Yeow Lai Chee dan sebagainya. Sementara itu, kaedah pengkaryaan koreografi amalan Hijikata yang berdasarkan Butoh-Fu, telah diperkenalkan oleh Yukio Waguri. Dengan melibatkan diri penulis ke dalam produksi Reminiscene, perkaraperkara yang berkaitan dengan kepenggunaan dan keberkesanan Butoh-Fu telah diperhatikan. Dengan data yang diperoleh, beberapa pemerhatian dalam kepenggunaan Butoh-Fu telah dikenal pasti dan diterangkan seperti berikut mengikut tema perbincangan.

\section{Latihan memaparkan imej kecacatan (Grotesque)}

Butoh-Fu membolehkan penulis merangkap penari merenung dan melaksanakan pergerakan yang melibatkan oto-otot yang halus (fine motor skill), terutamanya di bahagian muka, pergelangan tangan, jari dan pergelangan kaki. Latihan sebegini jarang dijumpai dalam seni tari secara umum. Kaedah latihan seumpana ini turut 'mamaksa' penari menghadapi 'kehodohan' yang tidak dipentaskan secara konvensional, terutamanya aksi herot-berot pada bahagian muka, dan pemutar belik yang terlampau seperti imej zombi yang kian kelihatan dalam filem. Penari perlu melatih keberanian dan keyakinan yang tinggi untuk melakonkan grostesque.

\section{Penerimaan kepelbagaian}

Butoh-Fu bertindak sebagai asas panduan rujukan dan bukan memaktubkan cara pergerakan seperti Labanotasi atau Notasi Benesh. Oleh itu, Butoh-Fu menerima kepelbagaian yang amat luas dari segi perekaan gerak fizikal kerana perekaan pergerakan adalah berbeza berdasarkan pengalaman masing-masing. Butoh-Fu adalah kaedah Penulisan Motif (Motif Writing) atau Deskripsi Motif (Motif Description) yang hanya mencadangkan satu kerangka pergerakan yang terarah. Walau bagaimanapun, keseragaman gerak dalam persembahan ensembel adalah susah dikawal kerana pengalaman latar belakang individu adalah berbeza. Konsep penyelidikan gerak yang direkakan perlu juga mengambil pertimbangan dari segi kesesuaian menurut pandangan budaya bangsa yang berbeza. 


\section{Penghayatan tari}

Berbanding dengan kaedah pengajaran dan pembelajaran tradisional yang didaktik (yang mana pengajar melakukan demostrasi sepenuhnya), penggunaan Butoh$F u$ tidak mengehadkan perkembangan kreativiti penari, tetapi melaksanakan gerak dengan imaginasi yang amat fantasi dan renungan pengalaman peribadi yang mendalam. Dengan erti kata lain, penari harus mencari-cari pengalaman yang berkaitan untuk merasionalisasikan $f u$ walaupun ia tidak masuk akal. Dalam hubung kait antara $f u$-gerak-emosi ini, tahap penghayatan penari boleh ditingkatkan kerana ia melibatkan aktiviti kognitif dan mental yang tinggi. Namun, kaedah ini hanya boleh diguna pakai ke atas penari yang terbuka dan tidak malu untuk berkongsi pengalaman yang terpendam serta rela melakukan pergerakan yang sangat aneh.

Foo Chi Wei, salah seorang penari Reminiscene telah meluahkan perasaannya dalam menyatakan kepentingan persembahan butoh yang membolehkan renungan kendiri, berdasarkan Butoh-Fu.

I have done a few workshops with Waguri San, I realized something. Of course, the contortion is part of what we learned, but most of the time is internalized the emotion or the feeling of it. A lot of visualization was done by internalization. Somehow you will feel that (internal part) when you started to project it out, and that was very difficult. In certain time, like just now, I actually felt something, when you felt the light going in. I don't know why automatically I teared out, so that is internalization. That is what I discovered throughout the whole experience most of the time in the workshops (Foo, C.W., Post production sharing session, 31 Ogos 2013).

\section{Metamorfosis}

Butoh-Fu secara khususnya dicipta untuk melatih penari dan mengembangkan material koreografi melalui metamorfosis. Namun, secara umumnya, Butoh$F u$ adalah satu kaedah yang mementingkan interaksi dalaman yang juga boleh diaplikasikan ke golongan bukan penari. Proses pengkaryaan butoh boleh 'membuangkan' personaliti luaran individu yang ketara dan menggalakkan sikap kesederhanaan dalam konteks persembahan ensembel. Walau bagaimanapun, penerangan metamoforsis melalui Butoh-Fu adalah sangat abstrak. Penerangan tersebut memerlukan komunikasi yang detail serta latihan fizikal yang berulangan - satu proses yang lama dan meletihkan. Ini boleh menyebabkan kehilangan minat di kalangan penari. 


\section{Butoh-Fu sebagai penerusan butoh yang asal}

Dalam menggalakkan kebebasan penerokaan metamorforsis fizikal, kaedah ini turut dianggap satu pendekatan yang paling mendekati dengan pengasas butoh Hijikata. Anggapan tersebut membenarkan pemain berasa dirinya istimewa kerana berpeluang membelajari butoh, terus daripada pewaris Hijikata Tatsumi - satu strategi untuk meningkatkan populariti dalam pasaran seni butoh, yang bersaing dengan pelbagai aliran latihan butoh yang berlainan. Butoh-Fu di sini dijadikan satu bukti autoriti profesionalisme bagi melangsungkan aliran latihan Hijikata.

Berdasarkan temu bual bersama Yukio Waguri, beliau berasa aneh untuk membahagikan seni butoh mengikut lokasi geografi seperti Butoh Malaysia, Butoh England, Butoh Thailand dan sebagainya. Beliau menegaskan butoh adalah untuk semua orang dan bebas daripada batasan negara. Walaupun kini terdapat pelbagai aliran latihan mengikut guru masing-masing, tetapi kaedah latihan Hijikata sebagai kaedah asas pengkaryaan butoh telah pun termaktub dalam Butoh-Fu, yang juga diperakui oleh institusi-institusi penyelidikan tertentu seperti Hijikata Tatsumi Archive, Keio Universiti Art Center, Jepun.

Berdasarkan penyelidikan Butoh-Fu ini, penulis merenungkan kepenggunaan sistem notasi yang terdapat di Malaysia. Selain daripada Labanotasi yang digunakan di dalam domain akademik, agensi-agensi seperti Jabatan Kebudayaan \& Kesenian Negara serta Yayasan Warisan Johor juga berusaha membangunkan sistem notasi tersendiri yang terdiri daripada rajah dan deskripsi untuk tujuan dokumentasi, pemeliharaan dan penerusan tari tradisional Melayu (Ahmad Omar, 2005; Md Ismail \& Leng, t.t.; Mohd Anis, 2014, 2007; Yayasan Warisan Johor, t.t.; Zuriah, 2016a, 2016b). Walau bagaimanapun, peranan dan kepenggunaan sistem notasi ciptaan tersendiri ini dalam aspek pemeliharaan, pelestarian dan penghasilan koreografi tari masih belum diterokai; suara dan kebijaksanaan para pencipta sistem notasi tempatan masih belum dihargai. Kepenggunaan dan peranan Butoh-Fu sebagai satu sistem notasi tersendiri mungkin boleh dijadikan salah satu rujukan untuk membantu melancarkan pembangunan sistem notasi ciptaan tempatan yang lebih lengkap untuk konteks penyelidikan, pemeliharaan dan pendidikan seni tari tempatan. 


\section{NOTA}

${ }^{1}$ Sila rujuk lukisan seni pada https://www.wikiart.org/en/paul-delvaux/the-night-garden-1942.

\section{RUJUKAN}

Ahmad Omar, H.I. (2005). Joget gamelan Terengganu \& Pahang: Penerus tradisi seni persembahan istana Kesultanan Melayu Melaka. Kuala Lumpur: JKKN Ministry of Cultural Arts and Heritage Malaysia.

Baird, B., \& Candelario, R. (Eds.). (2019). The Routledge companion to Butoh performance. Oxon: Routledge.

Chilvers, I. (2003). Concise dictionary of art \& artists. New York: Oxford University Press.

Fraleigh, S.H. (2010). Butoh: Metamorphic dance and global alchemy. Urbana: University of Illinois Press.

Gonzales, J. (2019). Koreografi kontemporari Malaysia. Kuala Lumpur: SIRD.

Karaoğlu, S. (2020). De-/Re-militarization of Japan: Does Article 9 of the Japanese Constitution prevent Japan's Sovereignty? doi: 10.13140/RG.2.2.13133.05604.

Klein, S.B. (2007). Ankoku Butoh: The premodern and postmodern influences on the dance of utter darkness. (Chen, Y.Z., trans.). New York: The Cornell East Asia Series (Original work published 1989).

Leng, P.G. (2009). Persembahan butoh di Malaysia. Tirai Panggung, 9, 25-36.

Leng, P.G. (2011). The making of Malaysian contemporary dance by Chinese choreographers and dancers. In Mohd Anis, M.N. \& Burridge, S. (Eds.). Sharing Identities: Celebrating Dance in Malaysia (pp.111-129). New Delhi: Routledge.

Lim, S.L. (2014). Gender performativity in butoh: Gender subversion by Nyoba Kan in Malaysia. (Unpublished master's thesis). University of Malaya, Kuala Lumpur, Malaysia.

Ling, Y.L. (1998). Rì běn zhàn hòu xiăo jù chăng yùn dòng dāng zhōng de shēn tǐ yǔ kōng jiān [Trans: The body and space in movement of small theater in post war Japan]. Taipei: Taipei National University of the Arts Limited Publishing.

Md Ismail, Z., \& Leng, P.G. (Eds.) (t.t.). Pengisian buku kaedah pembelajaran Zapin negeri Johor tahun 2014. Unpublished manuscript. Johor Bharu: YWJ.

Mohd Anis, M.N. (1986). Randai Dance of Minangkabau with Labanotation Score. Kuala Lumpur: University of Malaya Department of Publications.

Mohd Anis, M.N. (1993). Zapin: Folk Dance of the Malay World. Singapore: Oxford University Press.

Mohd Anis, M.N. (1998). Malaysia. In Zainal Abiddin, T. (Ed.). The Dances of ASEAN (pp. 90-127). Brunei Darussalam: ASEAN Committee on Cultural and Information.

Mohd Anis, M.N. (2007). Nota kursus untuk Bengkel Kejurulatihan Tari 2007 Yayasan Warisan Johor: Latar Belakang Ringkas Tarian Zapin Johor. Johor Bharu: Yayasan Warisan Johor.

Mohd Anis, M.N. (2008). Dance research and performance. In Mohd Anis, M.N. \& Gonzales, J. (Eds.). Independence \& Identity (pp. 1-10). Kuala Lumpur: ASWARA \& Ministry of Unity, Culture, Arts and Heritage Malaysia.

Mohd Anis, M.N. (2014). Between orality and dance notation: Reviving Zapin dance and music as cultural heritage. In Fiskvik, A.M. \& Stranden, M. (Eds.). (Re)Searching the Field: Festchrift in Honour of Egil Bakka. Bergen: Fagbokforlaget. 
Waguri, Y. (Writer \& Editor), Goto, M. (Producer). (2004). Butoh kaden (2nd ed.) [DVD]. Tokyo: Yukio Waguri \& Kohzensha/nousite.inc.

Yayasan Warisan Johor. (t.t.). Lakaran Gerak Zapin Johor [Training course booklet]. Johor Bharu: Yayasan Warisan Johor.

Zuriah, M. (coordinator). (2016a). Modul InspiTari 2015. Kuala Lumpur: Jabatan Kebudayaan dan Kesenian Negara.

Zuriah, M. (coordinator). (2016b). Modul InspiTari 2014. Kuala Lumpur: Jabatan Kebudayaan dan Kesenian Negara.

\section{Temu bual}

Yeow, L.C., 17 Julai 2019.

Waguri, Y., 30 Ogos 2013. 


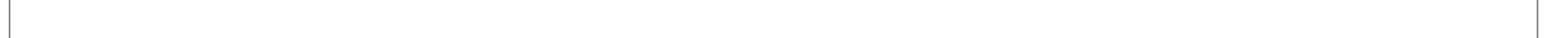

